\title{
NUT carcinoma: a rare and devastating neoplasm
}

\author{
Shinban Liu, George Ferzli
}

General Surgery, NYU Langone Medical Center, Brooklyn, New York, USA

\section{Correspondence to \\ Dr Shinban Liu,}

shinban.liu@nyumc.org

Accepted 18 August 2018

\section{DESCRIPTION}

A 45-year-old woman with no significant medical history had 1 month of productive cough empirically treated with azithromycin and dyspnoea on exertion. She was never a smoker and denied any constitutional symptoms, including unexpected weight loss. A CT of the chest was performed after she developed haemoptysis, which demonstrated a $6.3 \times 4.6 \mathrm{~cm}$ right hilar mass with hilar, subcarinal and cardiophrenic adenopathy (figure 1A). She underwent bronchoscopy which revealed complete occlusion of the right middle lobe by a tumour extending into the bronchus intermedius. Debridement of this mass was performed, with re-establishment of airway patency to the right lower lobe. Pathology from the debrided tumour as well as the subcarinal lymph node was consistent with poorly differentiated non-small cell lung carcinoma with Thyroid Transcription Factor 1 (TTF-1) and Programmed Death-Ligand 1 (PD-L1) negativity. Due to high clinical suspicion, the tissue samples were transferred to another facility for additional assessment. MRI of the head was performed and found to be negative for metastatic disease. This was followed by a positron emission tomography-CT performed 3 weeks after the original CT, which demonstrated intense Fludeoxyglucose (FDG) activity and significantly enlarged mass now measuring $11 \times 10 \mathrm{~cm}$ with bilateral pleural effusions, pericardial effusion, and mass effect on the superior vena cava, right atrium, left atrium and right pulmonary veins (figure 1B). Shortly after imaging, the patient's clinical status rapidly deteriorated and she expired after transition to hospice care. Her pathology would ultimately return indicative of NUT (nuclear protein in testis) carcinoma with a nuclear speckled pattern of staining, expression of BRG1 (SMARCA4) and BAF-47 INI1 (SMARCB1) retained in tumour cells.
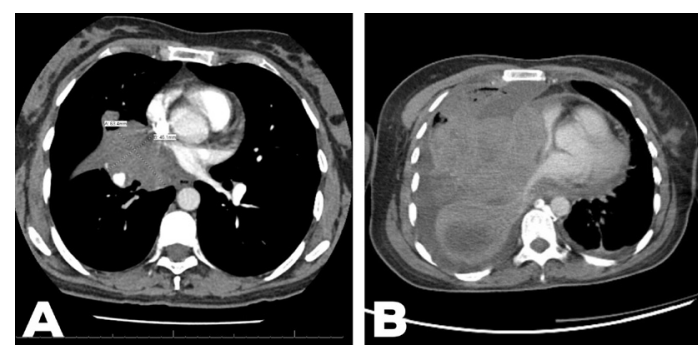

Limited 2018. No commercial re-use. See rights and permissions. Published by BMJ.

To cite: Liu S, Ferzli G. BMJ Case Rep Published Online First: [please include Day Month Year]. doi:10.1136/ bcr-2018-226526

mass. (B) Positron emission tomography-CT 3 weeks later with significantly increased $11 \times 10 \mathrm{~cm}$ right hilar mass, bilateral pleural effusions, pericardial effusion, and mass effect on the superior vena cava, right atrium, left atrium

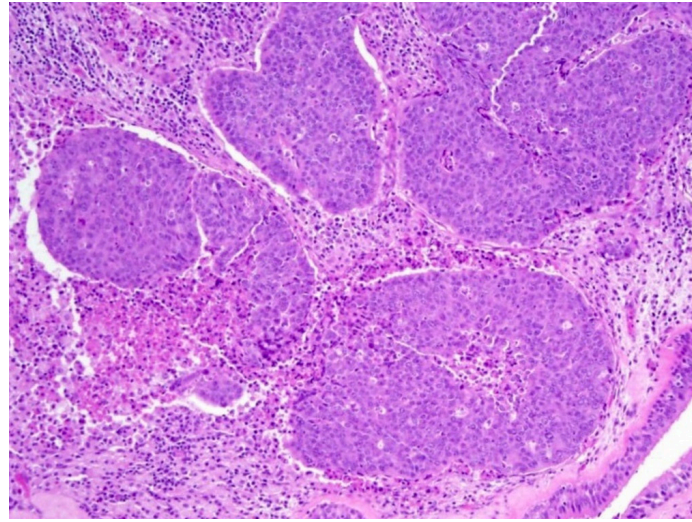

Figure 2 Characteristic histopathology of NUT (nuclear protein in testis) carcinoma with sudden, abrupt islands of well-differentiated squamous epithelium without gradual transition.

NUT carcinoma (formerly recognised as NUT midline carcinoma or NMC) is a very aggressive neoplasm characterised by a balanced translocation of the NUT gene on chromosome $15 \mathrm{q} 14 .{ }^{1}$ The most frequent translocation is $t(15 ; 19)$ and the role of this gene is largely unknown. However, this mutation is believed to alter squamous differentiation causing characteristic abrupt islands of well-differentiated squamous epithelium on histology (figure 2). NUT tumours can affect any organ system but typically appear in the midline upper respiratory tract and chest. This leads to generalised symptoms such as pain, weight loss and fatigue, with local obstructive mass effect depending on the organ system affected. The presence of sudden squamous differentiation without gradual differentiation on histology, in addition to midline location, should prompt further work-up with cytokeratin testing or NUT-specific antibody testing. It is exceptionally rare, with only 20-30 diagnoses reported in the USA each year. ${ }^{2}$ However, this may be a gross underestimate as few facilities have the reagents and expertise to make the diagnosis, and NUT tumour histology often overlaps with other carcinomas. Most patients have advanced metastatic disease at the time of diagnosis, and treatment is often limited to chemotherapy

\section{Learning points}

NUT (nuclear protein in testis) carcinoma is a rare neoplasm that should be clinically suspected with aggressive midline masses. and right pulmonary veins. 
and/or radiation therapy as surgical resection is not achievable. Treatment for these locally aggressive tumours generally follows the guidelines for tumours of similar histology and anatomical location.

Contributors SL and GF have contributed equally to the clinical investigation, writing and editing of this manuscript.

Funding The authors have not declared a specific grant for this research from any funding agency in the public, commercial or not-for-profit sectors.
Competing interests None declared.

Patient consent Next of kin consent obtained.

Provenance and peer review Not commissioned; externally peer reviewed.

\section{REFERENCES}

1 French CA, Ramirez CL, Kolmakova J, et al. BRD-NUT oncoproteins: a family of closely related nuclear proteins that block epithelial differentiation and maintain the growth of carcinoma cells. Oncogene 2008;27:2237-42.

2 French CA. Demystified molecular pathology of NUT midline carcinomas.J Clin Pathol 2010;63:492-6.

Copyright 2018 BMJ Publishing Group. All rights reserved. For permission to reuse any of this content visit

http://group.bmj.com/group/rights-licensing/permissions.

BMJ Case Report Fellows may re-use this article for personal use and teaching without any further permission.

Become a Fellow of BMJ Case Reports today and you can:

- Submit as many cases as you like

- Enjoy fast sympathetic peer review and rapid publication of accepted articles

- Access all the published articles

Re-use any of the published material for personal use and teaching without further permission

For information on Institutional Fellowships contact consortiasales@bmjgroup.com

Visit casereports.bmj.com for more articles like this and to become a Fellow 